\title{
A Study on the Tracing of the Fiber Connections of the Subfornical Organ by Using a Single Fluoresence Labelling Tracer, 4',6-Diamidino-2- Phenylindol Dihydrochloride (DAPI)
}

\author{
Daryanto
}

\begin{abstract}
Abstrak
Salah satu metode pelacakan lintas sarafi secara anatomik telah digunakan untuk melacak hubungan sarafi antara organum subfornicale dengan beberapa nukleus di dalam otak. Substansi pelacak fluoresens tunggal 4',6-diamidino-2-phenylindol dihydrochloride (DAPI) ditanamkan (disuntikkan) ke dalam organum subfornicale tujuh ekor tikus putih dewasa galur Wistar. Hasil memperagakan bahwa DAPI ternyata dapat ditransportasikan melalui akson secara retrograd, dan memberi "tanda" (label) fluoresensi badan sel saraf induk (corpus neurocyti) pada nucleus preopticus medialis, nucleus preopticus antero-medialis, nucleus preopticus antero-ventralis, caudatus putamen, nucleus periventricularis hypothalami, nucleus preopticus lateralis, nucleus paraventricularis hypothalami, nucleus latero-anterior hypothalami, nucleus supraopticus, nucleus hippocampalis dorsalis, area hypothalamus anterior. nucleus amygdaloid, fimbriae hippocampi dan alveus hippocampi. Kesimpulan yang dapat diambil dari penelitian ini ialah bahwa DAPI dapat memberi "tanda" (label) empat belas nuklei lain di dalam otak secara retrograd, dan secara anatomik memperagakan organum subfornicale dihubungkan dengan keempat belas nuklei di dalam otak tersebut.
\end{abstract}

\begin{abstract}
One of the anatomical-tract tracing methods was used to trace the anatomical connections between the subfornical organ (SFO) and several nuclei in the brain. A single fluorescent tracer, 4 ' 6 - diamidino-2-phenylindol dihydrochloride (DAPI) (WAKO), was injected in the SFO of seven adult albino rats of the Wistar strain. The results demonstrated that DAPI was found to be retrogradely transported through the axons, and this substance showed a characteristic fluorescent labeling of the parent cell bodies, in the medial preoptic nucleus, antero-medial preoptic nucleus, antero-ventral preoptic nucleus, caudatus-putamen, periventricular nucleus, lateral preoptic nucleus, paraventricular mucleus, lateroanterior hypothalamic nucleus, supraoptic nucleus, dorsal hippocampal nucleus, anterior hypothalamic area, anygdaloid nucleus, fimbria hippocampi and alveus hippocampi. This investigation demonstrated that DAPI was found to be able to label the parent cell bodies of those nuclei mentioned above only retrogradely and the subfornical organ were anatomically connected with those nuclei.
\end{abstract}

Keywords : 4,6-Diamidino-2-phenylindol dihydrochloride, Subfornical organ

\section{INTRODUCTION}

The subfornical organ (SFO) is one of the so-called circumventricular organs of the brain. The SFO is located in the third ventricle cerebri and attached to the base of the hippocampal commissure or ventral psalterium or rostral wall above the interventricular foramen and protrudes into the lumen of the third ventricle cerebri at the intersection between the two lateral and third ventricle. ${ }^{1,2,3}$ It is a small structure, possessing distinct morphological features that set it apart from other central nervous system nuclei ${ }^{3}$ and contains neurons, glial cells and a dense plexus of fenestrated capillaries. ${ }^{1,3}$

The SFO has attracted considerable attention because of its unusual structural characteristic and its location within the cerebral ventricular space. Dorsally it is continuous with the fornix, its ventral ependymallined surface is covered partially by the diverging branches of the choroid plexus. ${ }^{2}$ 
Morphologically it is highly vascular; ${ }^{3,4}$ it lacks a blood-brain-barrier ${ }^{2,5,6}$ and is an attachement place for all the choroid plexi of the forebrain.

Shute and Lewis ${ }^{7}$ and Lewis and Shute ${ }^{8}$ reported that fibers containing acetylcholinesterase (ACh.E) originate in the septum and project to the SFO and the organum vasculosum of the lamina terminalis (OVLT). It was concluded that cells in the dorsal fornix (above the hippocampal commissure) and others in the upper septum near the midline raphe send fibers to the SFO.

The afferent connections of the subfornical organ and the supraoptic crest have been investigated by means of the Fink-Heimer and Golgi-Cox methods. ${ }^{9}$

Miselis and colleagues has identified a substantial system of the efferent fibers emanating from the SFO. ${ }^{10,11}$ Recent anatomical ${ }^{11,12,13}$ and physiological studies ${ }^{14}$ indicated that the SFO is in fact a nucleus with neurons that appear to innervate directly other neurons in the paraventricular and supraoptic nuclei that release vasopressin from the posterior pituitary, as well as neurons in the medial preoptic nucleus that project to those nuclei. ${ }^{13,15}$

Tanaka et $a l^{16}$ suggested that lateral hypothalamic area (LHA) has an excitatory influence on the activity of neurons in the region of the SFO with efferent projections to the paraventricular nucleus (PVN) and that the influence may be mediated by angiotensin-II (A-II) receptor.
Lind ${ }^{17}$ suggested that the SFO is involved in the control of fluid balance and that serotoninergic-raphe projection to the SFO may participate in the relay of visceral sensory information.

Lind et al. ${ }^{12}$ using an horseradish peroxidase (HRP) technique stated that injection into the SFO labeled the neurons in the medial septum, medial preoptic nucleus, dorsal preoptic region and anterior hypothalamus. The physiological and behavioral fluid regulatory responses triggered by circulating A-II are also initiated when two clasical neurotransmitters, acetylcholine and serotonin are injected into the SFO. ${ }^{18}$ This suggested the presence of neural afferent employing these neurotransmitters but the characterization of neural inputs to the SFO lacked the proof of the presence of efferents.

The SFO participate in A-II-induced ${ }^{19,20,21}$ and acetylcholine- induced drinking. ${ }^{18,22,23}$

SFO neurons have been shown to project both into the paraventricular and supraoptic nuclei of the hypothalamus. ${ }^{11,12,24} \mathrm{McKinley}$ et al $^{25}$ stated in their investigation using autoradiographic studies that the greatest A- II-binding occured in the OVLT, SFO and medial preoptic and periventricular nuclei situated in the anterior third ventricle wall.

The objective of this investigation is to know whether the single fluorescent tracer DAPI can be used for tracing the parent cell bodies by retrograde transportation, to trace the connections between the SFO and other nuclei in the brain, and to know how far the nerve connections occur anatomically.

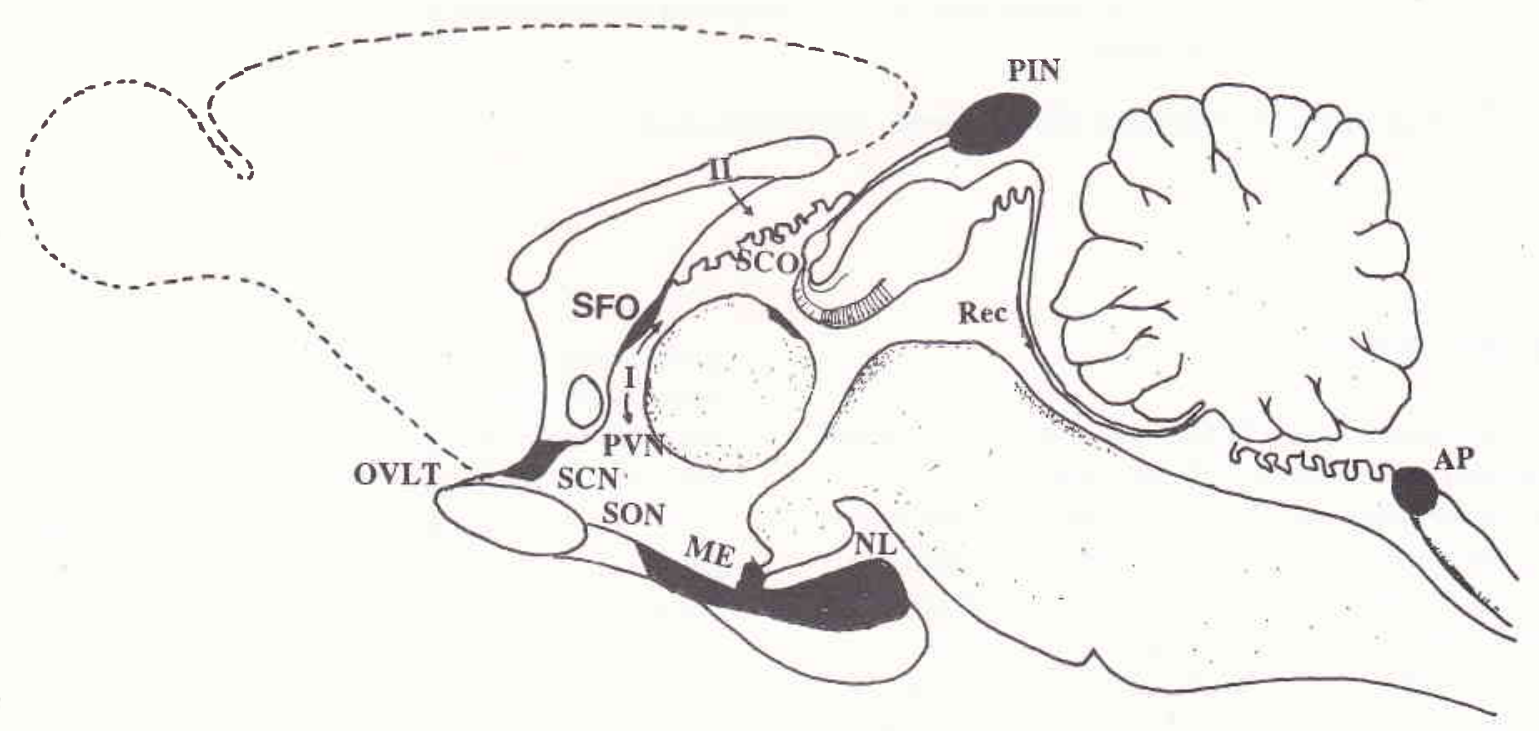

Figure 1. Median sagittal view of the rat brain, showing the location of the subfornical organ among the circumventricular organ: $A P=$ area postrema; $M E=$ median eminence $N L=$ neural lobe; $O V L T=$ organum vasculosum of the lamina terminalis; $P I N=$ pineal organ; Rec. $=$ recessus collicularis of the aqueduct; $S F O=$ subfornical organ; $S C O=$ subcommissural organ . I. Cerebral third ventricle; II. Choroid plexuses.

(From Weindl \& Sofroniew, ${ }^{35}$ ) 


\section{MATERIALS AND METHODS}

Seven adult male rats of the Wistar strain (Japan Clea Co.), weighing between 250-350 gr were used in this experiment. Each animal was anaesthetized with an intraperitoneal $10 \%$ chloralhydrate $(3 \mathrm{ml} / \mathrm{Kg})$ and the head mounted on a stereo-taxic frame. One small hole in the skull was made into which a fine micropipette filled with a small amount of 4, 6-diamidino-2phenylindol dihydrochloride (DAPI, Wako) was perpendicularly inserted into the subfornical organ.

The location of the hole and the depth of the penetration of the glass micropipette was determined empirically using the animal's weight and also the rats brain atlas. The bregma was taken as the point of referrence to establish a fixed relation between measurement and geometry of the head where the hole is to be drilled. The location of the subfornical organ were $1,4 \mathrm{~mm}$ behind the bregma, $1 \mathrm{~mm}$ lateral to the sulcus sagittalis (para sagittalis), the depth was $4,31 \mathrm{~mm}$ and at an angle of $12,5^{\circ}$ to the stereotaxic vertical plane (see Figure 2). ${ }^{26}$

The volume of the injected solution was 0,03 $0,04 \mu 1$ of $2,5 \%$ DAPI. The solution was delivered into the subfornical organ via a glass micropipette connected to a mycrosyringe over a period of $1-5$ minutes. Each animal was allowed to survive for $48-72$ hours and individually placed in a cage covered by a paper box and given ad lib. food and water in a dark room, and sacrified by an intraventricular perfusion of $10 \%$ formalin in phosphate buffer under $10 \%$ chloralhydrate deep anaesthesia; thereafter the whole brain was removed.

The brain was further immerse in 10\% formolsaline $(\mathrm{pH} 7,3)$ for a while and cut serially in frontal slices of $20 \mu \mathrm{m}$ thickness on a cryostat. The specimens were air-dried in a dark box and covered with nonfluorescent glycerine. Two out of every 5 sections were mounted on clean glycerine-coated glass slides and the exact site of injection as well as the extent of diffusion within each structure was examined.

The sections were microscopically examined under fluorescent microscope (Nikon Optiphot-EF) with a filter system of $\mathrm{U}+420 \mathrm{~K}$.

Thereafter the exact location of the labelled cells was depicted in the large map $(18 \mathrm{X})$ of the brain section (camera lucida drawings).

\section{RESULTS}

Seven animals had localized of DAPI in the subfornical organ.

The results of this investigation demonstrated that the single fluorescent tracer (DAPI) has labeled the parent cell bodies of the neurons in the medial preoptic nucleus, antero-medial preoptic nucleus, antero-

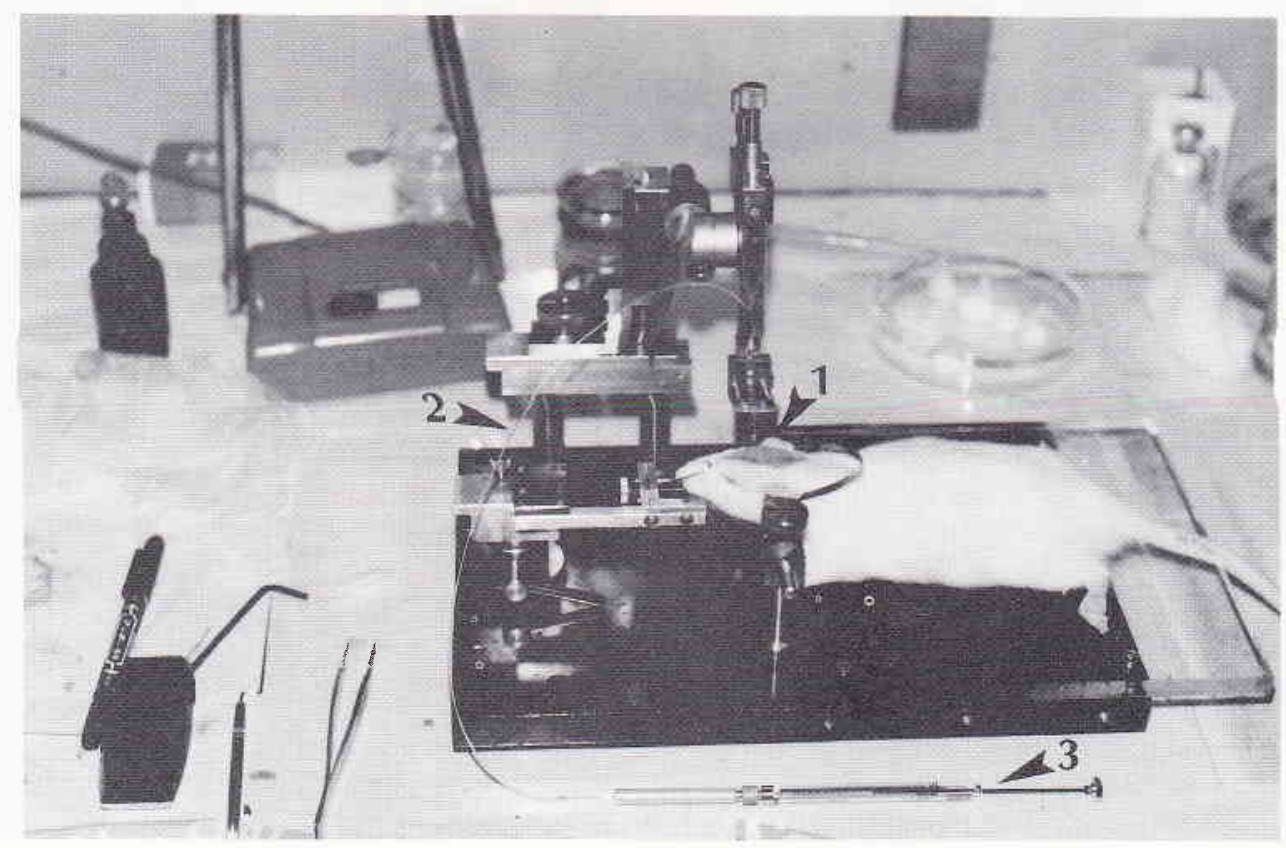

Figure 2. The figure showing a position of the rat in the stereotaxic apparatus: 1 . glass micropipette filled by single fluorescent tracer DAPI; 2. polyethylene tube $(P E-20)$ and 3. Hamilton's microsyringe. 
ventral preoptic nucleus, lateral preoptic nucleus, periventricular hypothalamic nucleus, putamen-caudate, paraventricular nucleus, latero-anterior hypothalamic nucleus, supraoptic nucleus, dorsal hippocampal nucleus, anterior hypothalamic area, amygdala nucleus, fimbriae hippocampi, alveus hippocampi and dorsomedial hypothalamic nucleus.

Figure 3 is a frontal section of the brain, showing the sites of DAPI injection (arrow) and the SFO filled with injected label to all areas of the SFO.

Figure 4 is a frontal section of the rat brain at the stereotaxic coordinated of IA (interaural) $8,74 \mathrm{~mm}$ and bregma - 0,26 $\mathrm{mm}$ showing examples of sites of the DAPI labeled parent cell bodies and nerve fibers in the medial preoptic nucleus.

Figure 5, 6, 7, 8 and 9 showed the distribution of labeled parent cell bodies of the neurons. These figures have been reproduced to depict the topography of the neurons. The color of the labeled parent cell body is a clear white upon a blue colored back ground. The results revealed that both fibers and parent nerve cell bodies are clearly labeled.

\section{DISCUSSION}

In this study the afferent nerve connections between the subfornical organ and other nuclei in the brain were examined by a single fluorescent tracer (DAPI), using one of the neuroanatomical-tract tracing methods, which was developed by Heimer and Robards. ${ }^{27}$

Injection of a single fluorescent tracer (DAPI) in seven adult albino rats of the Wistar stain, demonstrated that DAPI has labeled the parent cell bodies of the neurons in the medial preoptic nucleus, antero-medial preoptic nucleus, antero-ventral preoptic nucleus, lateral preoptic nucleus, periventricular hypothalamicnuleus, putamen-caudate, paraventricular nucleus, latero-anterior hypothalamic nucleus, supraoptic nucleus, dorsal hippocampal nucleus, anterior hypothalamic area, amygdaloid nucleus, fimbriae hippocampi, alveus hippocampi and dorso-medial hypothalamic nucleus.

The projections of nerve fibers to the subfornical organ from those nuclei mentioned above were verified by the retrogradely transported DAPI. These results suggest that all of the labelled nerve fibers that were traced from the SFO are afferents from those nuclei, according to the observations that the labeled axons can be followed to the retrogradely labeled neurons that may have given rise to them. The conclusion is that DAPI was taken up by axon terminals and transported retrogradely to the parent cell bodies in those nuclei.

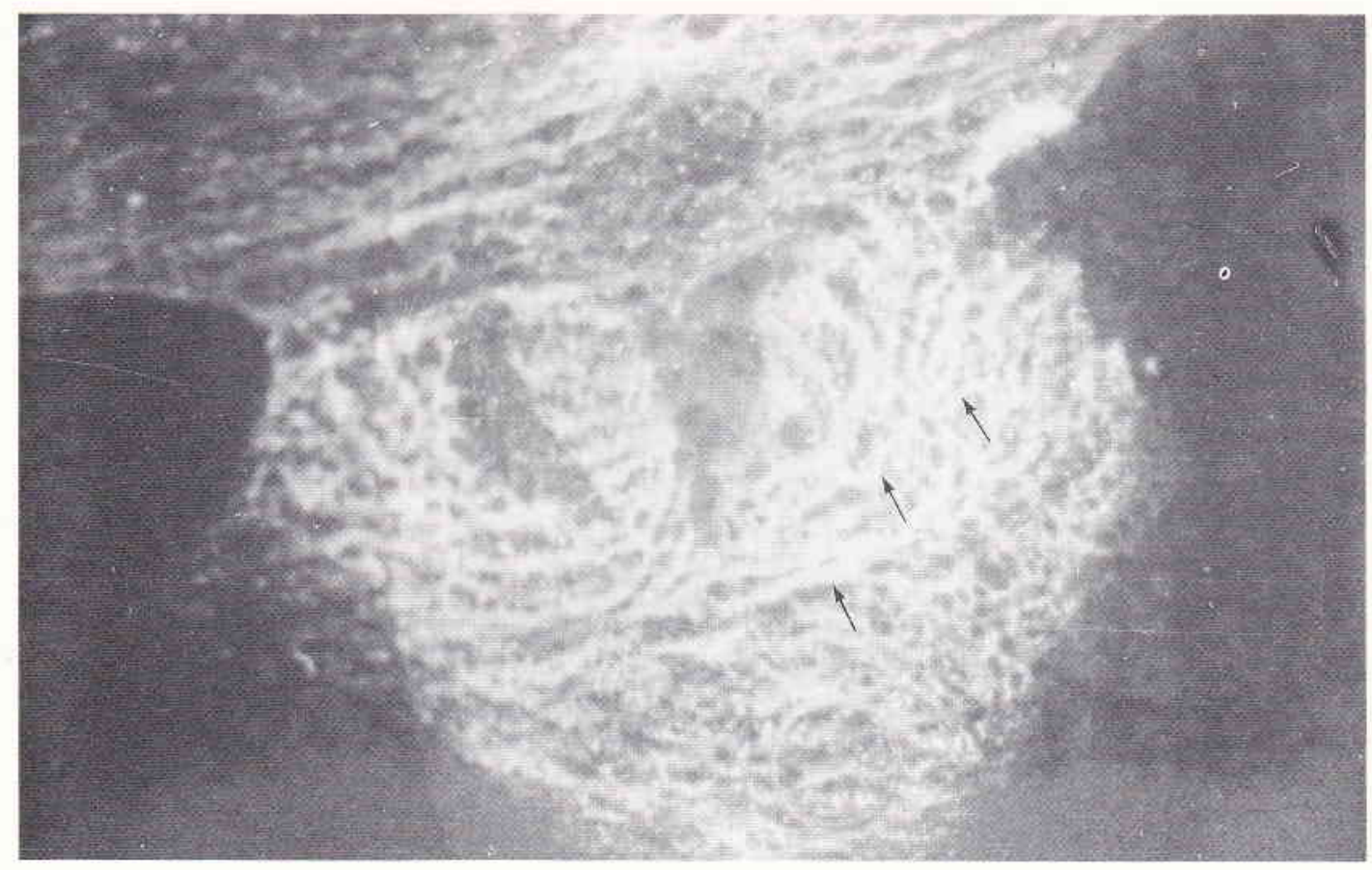

Figure 3. A frontal section of the rat hrain at the stereotaxic coordinates between IA 7,60 mm and bregma-1,40 $\mathrm{mm}$ and IA 7,20 $\mathrm{mm}$ and bregma-1,80 mm showing examples of the sites of DAPI injection in the SFO (arrow). 


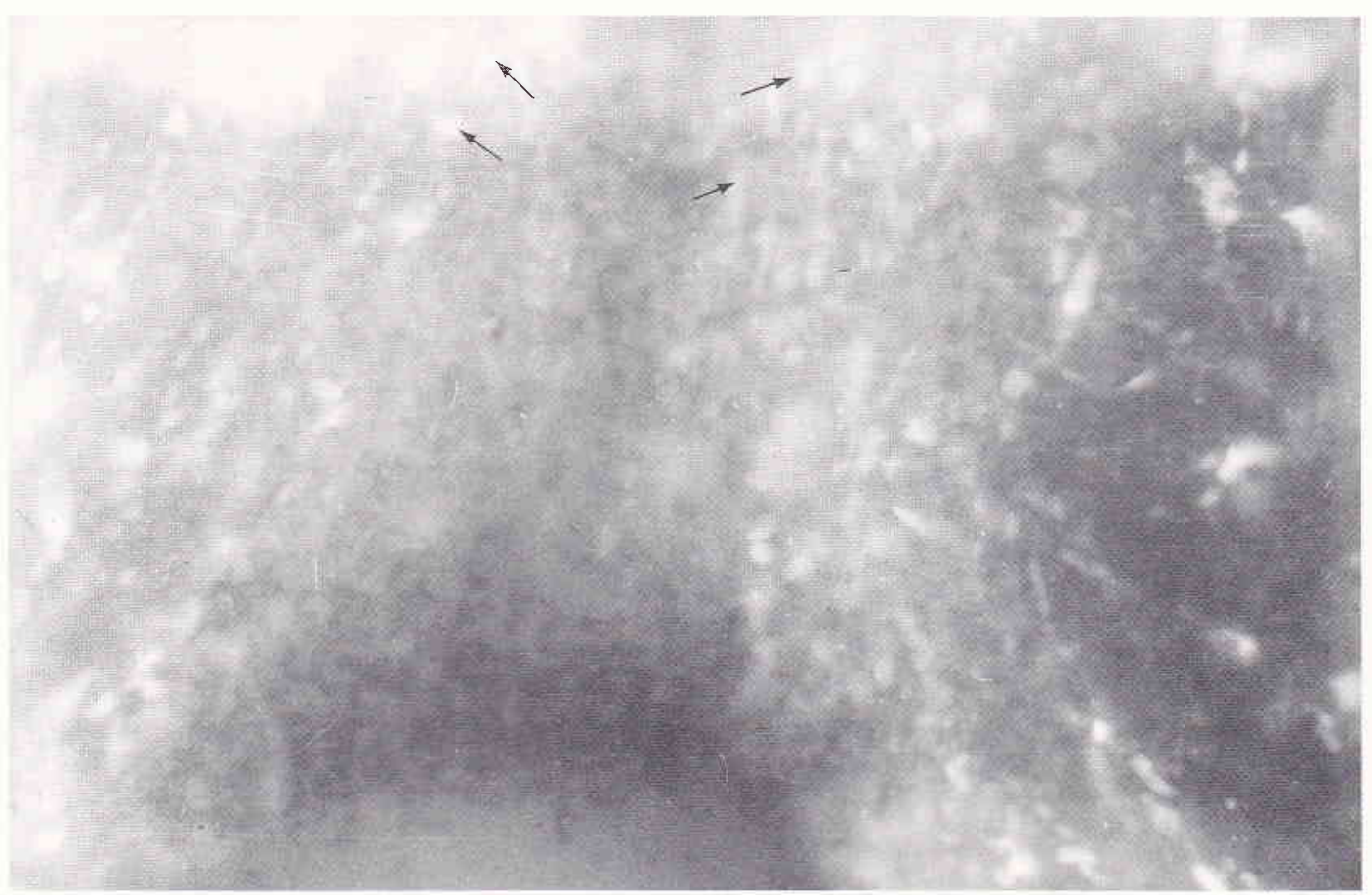

Figure 4. A frontal section of the rat brain at the stereotaxic coordinates of $I A \quad 8,74 \mathrm{~mm}$ and bregma- $0,26 \mathrm{~mm}$ showing examples of sites of DAPI labeled parent cell bodies and nerve fibers in the medial preoptic nucleus.

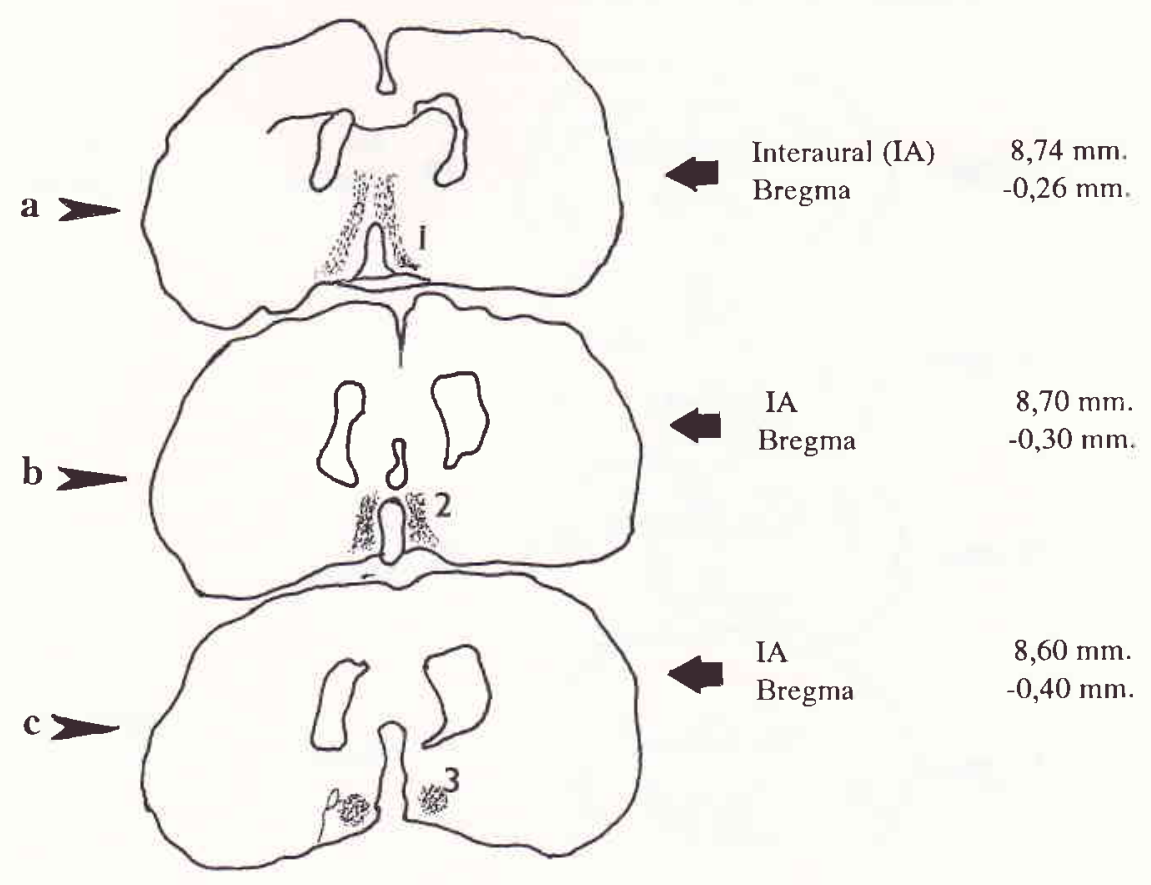

Figure 5. A camera lucida drawing of the frontal sections of the rat brain at the stereotaxic coordinates of: (a). IA (interaural) 8,74 mm and bregma - 0,26 mm (0,26 mm behind the bregma) showing the sites of the DAPI labeled parent cell bodies and nerve fibers in the medial preoptic nucleus (1). (b). IA $8,70 \mathrm{~mm}$ and bregma-0,30 mm showing the sites of the DAPI labeled parent cell bodies in the antero-medial preoptic mucleus (2). (c). IA 8,60 mm and bregma-0,40 mm showing the sites of the DAPI labeled parent cell bodies in the anteroventral preoptic mucleus (3). 


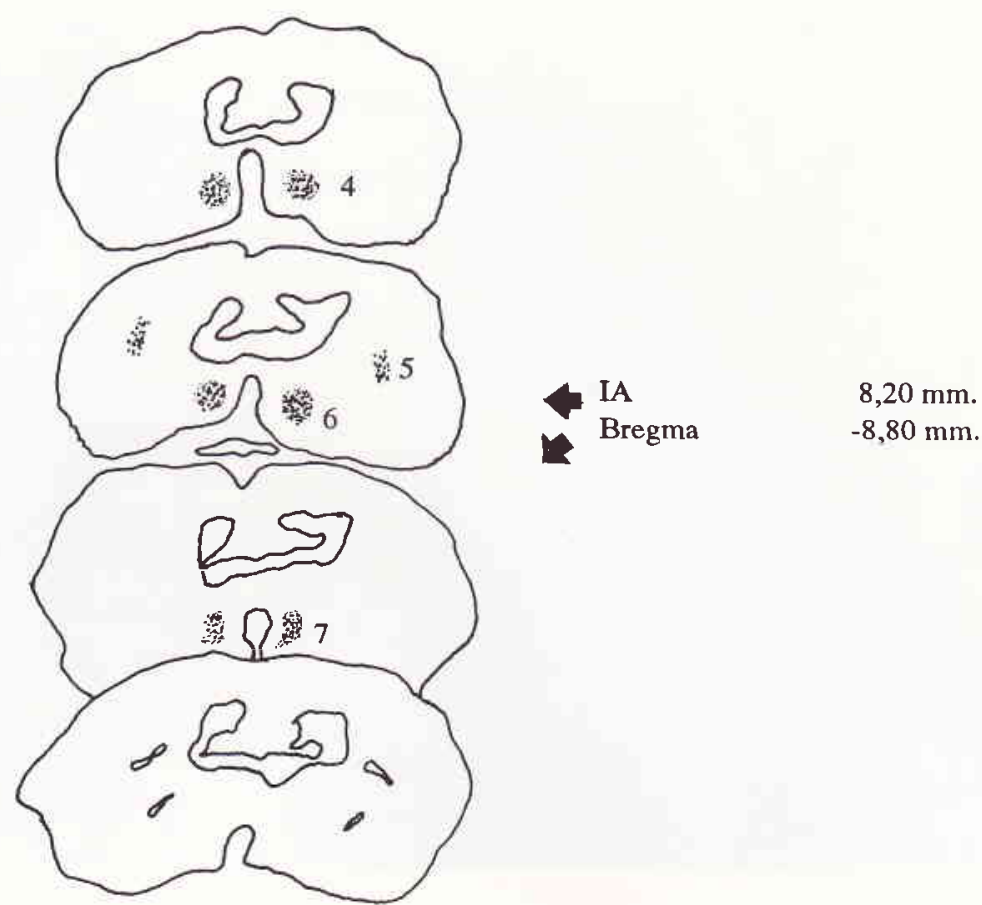

Figure 6. A camera lucida drawings of the frontal section of the rat brain, at the stereotaxic coordinates of IA 8,20 mm and bregma0,80 showing the sites of the DAPI labeled parent cell bodies in the hypothalamic periventricular nucleus (4), the caudate-putamen (5), medial preoptic nucleus (6) and lateral preoptic nucleus (7).

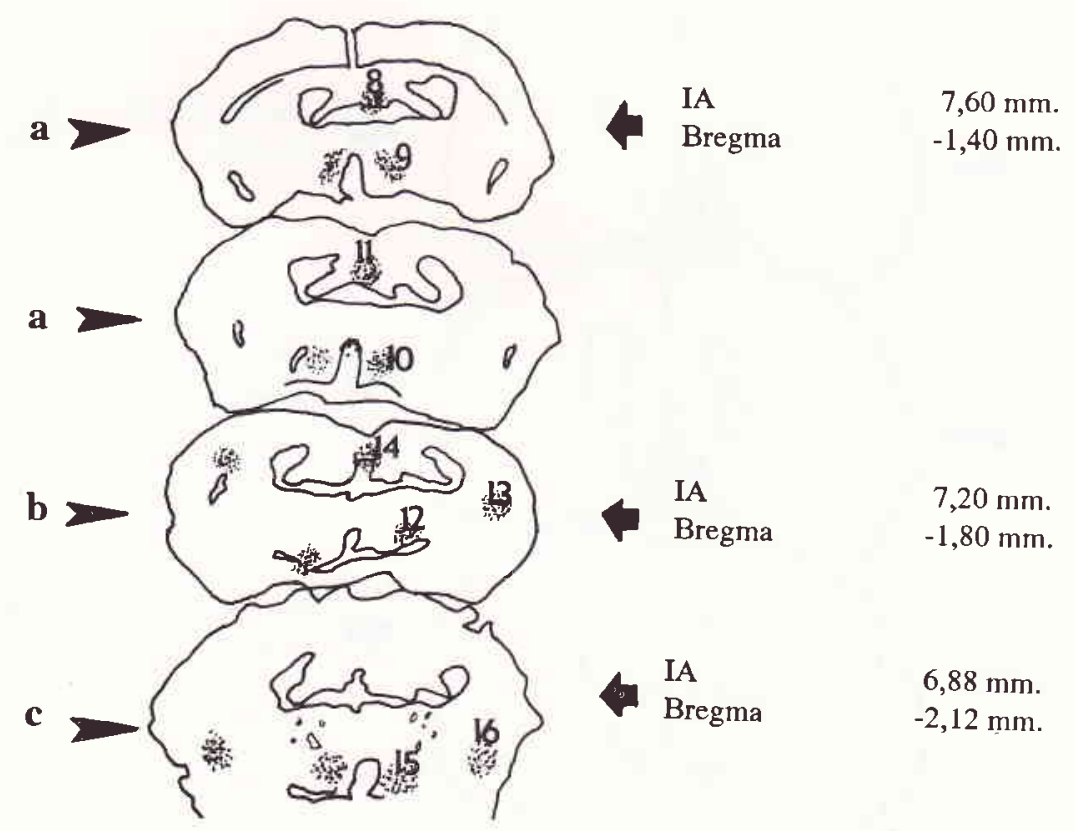

Figure 7. A camera lucida drawing of the frontal section of the rat brain, at the stereotaxic coordinates of (a). IA 7,60 $\mathrm{mm}$ and bregma -1,40 mm showing the sites of the DAPI labeled parent cell bodies in the paraventricular hypothalamic nucleus (9) and the lateroanterior hypothalamic nucleus (10). (b). IA 7,20 $\mathrm{mm}$ and bregma $-1,80 \mathrm{~mm}$ showing the sites of the DAPI labeled parent cell bodies in the supraoptic nucleus (12), the caudate putamen (13) and the dorsal hippocampal nucleus (14). (c). IA 6,88 mm and bregma-

$2,12 \mathrm{~mm}$ showing the sites of the DAPI labeled parent cell bodies in the anterior hypothalamic area (15) and the amygdaloid nucleus (16). 


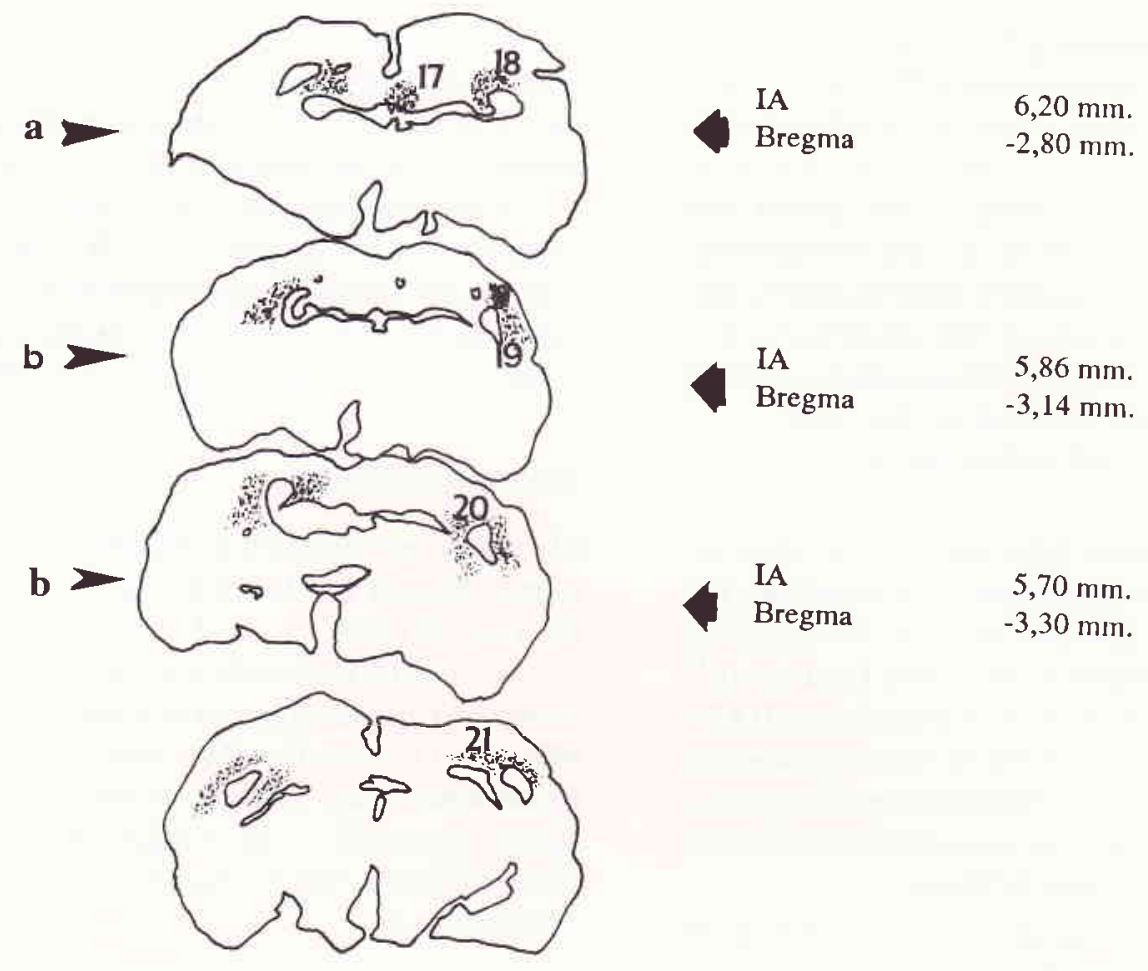

Figure 8. A camera lucida drawing of the frontal sections of the rat brain, at the stereotaxic coordinates of (a). IA 6,20 $\mathrm{mm}$ and bregma - 2,80 $\mathrm{mm}$ showing the sites of the DAPI labeled parent cell bodies in the dorsal hippocampal nucleus (17) and fimbriae hippocampi (18). (b). IA 5,86 mm and bregma - 3,14 mm and IA 5,70 mm and bregma-3,30 mm showing the sites of the DAPI labeled parent cell bodies in the fimbriae hippocampi $(19,21)$ and alveus hippocampi $(20)$.

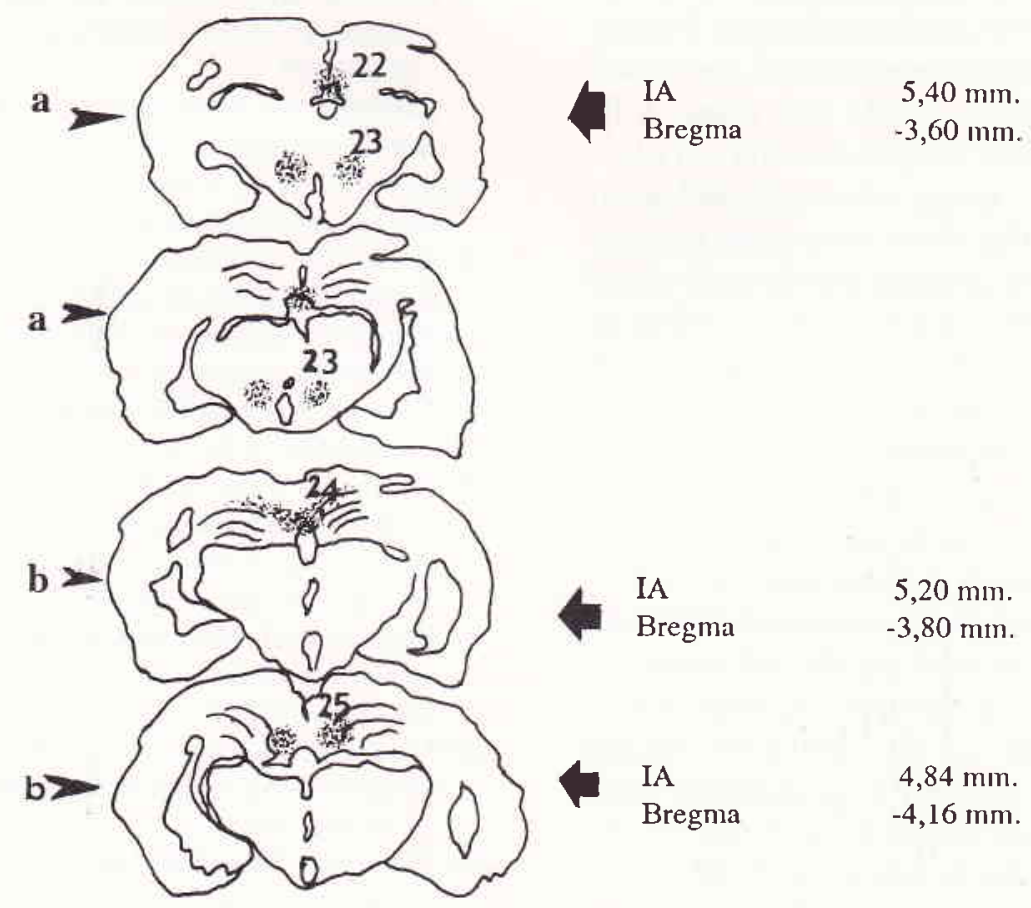

Figure 9. A camera lucida drawing of the frontal sections of the rat brain at the stereotaxic coordinates of (a). IA $5,40 \mathrm{~mm}$ and bregma-3,60 mm showing the sites of the DAPI labeled parent cell bodies in the dorsal hippocampal nucleus (22) and the dorsomedial hypothalamic nucleus (23). (b). IA 5,20 mm and bregma - 3,80 mm and IA 4,84 mm and bregma - 4,16 mm showing the sites of the DAPI labeled parent cell bodies in the fimbriae hippocampi (24 and 25). 
The intensity or density of the tracer in labeling the parent cell bodies showed some differences. There are some parent cell bodies which were labeled very clearly, but some other nuclei were less clearly. It might be caused by the location of the parent cell bodies which were too far from the site of injection. For example, the caudate-putamen nucleus, supraoptic nucleus and amygdaloid nucleus. The other factor was the time provided for DAPI to be transported over long distance from the axon terminal in the subfornical organ to label the parent cell bodies only $48-72$ hours, that was not enough.

Similar findings have been reported by other investigators using other techniques, for example, the neurons in the medial preoptic nucleus described by Hernesniemi et al., ${ }^{9}$ Akert et al., ${ }^{1}$ and Lind et al. ${ }^{12}$ behave on the same way as those labeled with DAPI. Likewise, the inputs to the SFO in the hippocampal commissure, nucleus septalis fimbrialis, medial preoptic nucleus, supraoptic nucleus have also been described by Akert et al. ${ }^{\prime}$ and Lewis \& Shute. ${ }^{8}$

Other investigators using electrophysiological methods, stated that there were some connections between the SFO and the supraoptic and paraventricular nuclei of the hypothalamus, ${ }^{28,29,30,31,32}$ and using the autoradiographic method and tracer's anterograde transportation demonstrated the connections between the medial preoptic nucleus, supraoptic nucleus, paraventricular nucleus with the subfornical organ. Tanaka et al. ${ }^{16}$ by using microiontophoresis which was based upon electrophysiological methods and using A-II, acetylcholine, saralasin and atropin, and Sgro et al., ${ }^{33}$ Yamashita et al. ${ }^{34}$ by using electrophysiological methods, demonstrated that there were some connections between the subfornical organ and the paraventricular nuclei. Miselis (1981) and Lind et al. (1984), in their investigations, stated that there were some reciprocal connections between the median preoptic nucleus and the subfornical organ. ${ }^{11,24}$

Lind et al. ${ }^{12}$ using one of the neuroanatomicaltract tracing methods and using horseradish peroxidase (HRP) as a tracer which was injected into the subfornical organ, demonstrated that injection of HRP into the subfornical organ will label parent cell bodies in the medial septum, medial preoptic nucleus, dorsal preoptic regions, and diffuse throughout the medial preoptic area and the anterior hypothalamic area. These results showed that all the nucleus that can be labeled by HRP, could also be labeled by DAPI.

Especially if compared with Lind's investigation, which used HRP, ${ }^{12}$ the use of DAPI has advantages and disadvantages. The advantage by using DAPI is that DAPI can label more nuclei than HRP, but DAPI can only trace in one direction, i.e. by retrograde transporatation. HRP, however, can trace in two directions, that means a reciprocal connection, since HRP is transported in both anterograde and retrograde directions.

This investigation, concluded that DAPI can be used to label the parent cell bodies only in one direction, i.e. by retrograde transportation, but it can label more nuclei and areas in the brain, especially when compared with other tracers, such as HRP.

\section{Acknowledgements}

My thanks are directed to ICMR for the funds granted to me through the JSPS Cooperation Programmes in the year of 1989 .

I would like to acknowledge the valuable supervision and encouragement by Prof. Takashi Yamadori, MD., Ph.D. from the First Department of Anatomy, Kobe University School of Medicine, Japan, The author gratefully acknowledge the assitance of Dr. Dong Kai (for camera lucida drawing, sectioning on cryostat etc.).

\section{REFERENCES}

1. Akert K, Potter HD, Anderson JW. The subfornical organ in Mammals. Comparative and topographycal anatomy. $J$ Comp Neurol 1961; 116:1-14.

2. Dellmann HD, Simpson JB. Regional differences in the morphology of the rat subfornical organ. Brain Res. 1976; 116:389-400.

3. Dellmann HD, Simpson JB. The subfomical organ. International Rev Cytol. 1979; 58:333-421.

4. Spoerri Von O. Uber die Gefassversorgung des Subfornikalorgans der Ratte. Acta Anat 1963; 54:333-48.

5. Andres KH. Der Feinbau des Subfornikalorgans von Hund. Z Zellforsch 1965; 68:445-73.

6. Rohr VU. Zum Feinbau des Subfornikal Organs der Katze I. Der Gefass-Apparat. Z Zellforsch 1966; 73:246-71.

7. Shute CCD, Lewis PR. The subfornical organ (intercolumnar tubercle) of the cat. $J$ Anat Lond 1963; 97:301.

8. Lewis PR, Shute CCD. The cholinergic limbic system; projections to hippocampal formation, medial cortex, nuclei of ascending cholinergic reticular system, and the subfomical organ and supraoptic crest. Brain 1967; 90:521-540.

9. Hernesniemi J, Kawana E, Bruppacher H, Sandri C. Afferent connection of the subfomical organ and supraoptic crest. Acta Anat 1972; 87:111-36.

10. Miselis RR, Saphiro RE, and Hand PJ. Subfornical organ efferents to neural systems for control of body water. Science 1979; 205:102-5.

11. Miselis RR. The efferent projections of the subfornical organ of the rats: A Circumventricular organ within a neural network subserving water balance. Brain Res 1981; 230:1-23.

12. Lind RW, Van Hoesen GW, and Johnson AK. An HRP study of the connections of the subfomical organ of the rat. J Comp Neurol 1982; 210:265-77. 
13. Sawchenko PE, Swanson LW. The distribution and cells of origin of some afferent projections to the paraventricular and supraoptic nuclei of the rat (abstract). Soc Neurosci 1981; $7: 325$.

14. Ferguson AV, Day TA, Renaud LP. Subfornical organ efferents influence the excitability of neurohypophyseal and tuberoinfundibular paraventricular nucleus in the rat. Neuroendocrinology 1984; 39:423-8.

15. Swanson LW. An autoradiographic study of the efferent connections of the preoptic region in the rat. J Comp Neurol $1976 ; 167: 227-56$.

16. Tanaka J, Kaba H, Saito H, Seto K. Lateral hypothalamic area stimulation excites neurons in the subfornical organ with efferent projections to the hypothalamic paraventricular nucleus in the rat. Brain res 1986; 379:200-3.

17. Lind RW. Bi-directional, chemically specified neural connections between the subfomical organ and midbrain raphe system. Brain Res 1986; 384:250-61.

18. Simpson JB, Routtenberg A. Subfornical organ lesions reduce intravenous angiotensin-induced drinking. Brain Res $1975 ; 88: 154-61$.

19. Eng R, Miselis RR. Polydipsia and abolotion of angiotensininduced drinking after transections of subfornical organ efferent projections in the rat. Brain Res. 1981; 225:200-6.

20. Lind RW, Johnson AK. Subfornical organ-median preoptic connections and drinking and pressor responses to angiotensin-II. J of Neuroscience 1982; 2 (8); 1043-51

21. Mangiapane ML, Simpson JB. Pharmacologic independence of subfornical organ receptors mediating drinking. Brain Res 1979; 178:507-17.

22. Padmowijoyo D. An investigation of the subfornical organ as a receptor for histamine, acerylcholine or angiotensin-II in mediating drinking behaviour (A Master thesis). Bangkok : Mahidol University, 1976

23. Simpson JB, Routtenberg A. Subfornical organ : acetylcholine application elicits drinking. Brain Res 1974; 69:15764 .

24. Lind RW, Swanson LW, Ganten D. Angiotensin-II-immunoreactive pathways in the central nervous system of the rat: evidence for a projection from the subfornical organ to the paraventricular nucleus of the hypothalamus. Clin and Exper - Theory and Practice. 1984; A6 (10 \& 11):1915-20.

25. McKinley MJ, Denton DA and Weisinger RS. Sensors for antidiuresis and thirst-osmoreceptors of CFS sodium detectors? Brain Res 1978; 141:89-103.

26. Paxinos G, Watson C. The rat brain, in steretotaxic coordinates. San Diego, New York, London, Toronto : Academic Press Harcourt Brace Jovanovich Publishers, 1986.

27. Heimer L, Robards MJ. Neuroanatomical-tract Tracing Methods. New York, London : Plenum Press, 1981.

28. Ferguson AV, Renaud LP. Hypothalamic paraventricular nucleus lesions decrease pressor responses to subfornical organ stimulation. Brain Res 1984; 305:361-4.

29. Ferguson AV, Day TA, Renaud LP. Subfornical organ efferents influence the excitability of neurohypophyseal and tuberoinfundibular paraventricular nucleus neurons in the rat. Neuroendocrinology 1984; 39:423-8.

30. Ferguson AV, Day TA, Renaud LP. Subfornical organ stimulation excites paraventricular neurons projecting to dorsal medulla. Am J Physiol 1984; 247:R 1088-RI092.

31. Renaud LP, Ferguson AV, Day TA, Bourque CW, Sgro S. Electrophysiology of the subfornical organ and its hypothalamic connections an In-Vivo Study in the rat. Brain Res Bull 1985; 15:83-6.

32. Ferguson AV, Kasting NW. Electrical stimulation in subfornical organ increase plasma vasopressin concentrations in the concious rat. Am J Physiol 1986; 251:R425-R428.

33. Sgro S, Ferguson AV, Renaud LP. Subfornical organsupraoptic nucleus connections: an electrophysiologic study in the rat. Brain Res 1984; 303:7-13.

34. Yamashita H, Osaka T, Kannan H. Effect of electrical stimulation of the paraventricular nucleus on neurons in the subfornical organ of cats. Brain Res $1984 ; 323: 176-80$.

35. Weindl A, Sofroniew MV. Neurohormones and circumventricular organs. In: Knigge KM, Scott DE, Weindl A editors. Brain-endocrine interaction III. Neuroal hormones and reproduction. Bassel : Karger, 1978; 117-37. 